\title{
Emotional Politics on Facebook. An Exploratory Study of Podemos' Discourse during the European Election Campaign 2014
}

\author{
Política y emociones en Facebook. Un estudio \\ exploratorio del discurso de Podemos en la campaña \\ electoral europea de 2014
}

\begin{abstract}
The results of the European elections 2014 in Spain were characterized by the outstanding rise of a new party, Podemos, which obtained five seats in the European Parliament, despite being founded few months before the elections. The present study analyzes both the content and the presence of emotions in Podemos' discourse on Facebook during the European electoral campaign. In particular, the affective content of both the party's discourse and the comments of its followers will be analyzed through a pragmatic linguistic approach applied to a corpus of 163 posts and 215 followers' comments. Results show an insistence on positive emotions in the party's discourse and a prevalence of negative emotions in the comments of the citizens.
\end{abstract}

Keywords: political discourse, European elections, Facebook, emotions, Podemos

Resumen

Los resultados en España de las elecciones al Parlamento Europeo de 2014 se caracterizaron por el surgimiento de un nuevo partido, Podemos, que, a pesar de haber sido fundado pocos meses antes de las elecciones, obtuvo cinco escaños en el Parlamento Europeo. En este trabajo analizamos el contenido y la presencia de emociones en el discurso de Podemos en Facebook durante la campaña electoral europea. Concretamente, se analiza el contenido afectivo del discurso del partido y de los comentarios de sus seguidores mediante una aproximación lingüística pragmática aplicada a 163 posts y 215 comentarios. Los 
resultados muestran una insistencia en emociones positivas por parte del partido y una prevalencia de emociones negativas en los comentarios de los internautas.

Palabras clave: discurso político, elecciones europeas, Facebook, emociones, Podemos

\section{INTRODUCTION}

The electoral campaign for the European Parliament Election in May 2014 found Spain in a multiple-crisis environment. In addition to the deep economic crisis and the social tensions derived from the austerity policies, the country was facing several political and institutional problems, such as the Catalan independence movement or the many corruption scandals affecting the central political parties. These circumstances, among others, led the Spanish citizenry to develop strong attitudes of mistrust and cynicism against political parties, politicians and politics itself, as shown by successive polls. ${ }^{1}$

This political scenario witnessed the emergence of a new political force, called Podemos, that was officially founded on January $16^{\text {th }}$, that is, four months ahead the European elections. Its main leader, Pablo Iglesias Turrión, $\mathrm{PhD}$ in Political Science and university professor, was a well-known political analyst in different television shows. Indeed, his popularity and his constant appearance in televised political debates helped him publicize his political project during the months before the elections.

Podemos was one of the new parties born before the European elections, which were inheritors of the $15 \mathrm{M}$ Movement, as it was the case of Partido X. All these parties made a massive use of the new communication channels during the campaign. According to Sanjuan (2015), Podemos had a website with detailed information on the European election and open to a participatory process, a Facebook account with a growing number of followers (149.000 during the campaign), an official Twitter account with 43.200 followers at the time of the election (besides personal accounts of the party's leaders), more than 7.700 followers in its YouTube channel and an account on Vimeo. Podemos presented itself as a party open to a participatory process, formed by ordinary citizens who were disenchanted with the traditional political parties and willing to get involved in public life. Its intense

1 See for example, the polls of the Spanish Centre for Sociological Research (CIS), which asks in periodical monthly surveys for the main problems that Spain is facing according to the citizenry. The results of the polls can be accessed at http://www.cis.es/cis/opencm/EN/11_barometros/depositados. jsp. 
rise in popularity translated into $8 \%$ of the total votes and five seats in the European Parliament.

This study aims to analyze the party discourse on Facebook during the European campaign 2014, focusing on the posts published on the party's Facebook profile and paying special attention to the emotional content of both the posts and the comments published by Podemos followers. ${ }^{2}$

\section{THEORETICAL BACKGROUND}

\subsection{Internet and electoral campaigns}

Political communication research has shown that electoral campaigns in Western countries are undergoing a process of modernization, whose main objective is to achieve the maximum level of electoral effectiveness through a series of techniques imported from corporate marketing (Maarek, 2009) and different refined ways of attracting media attention (Swanson and Mancini, 1996; Gibson and Römmele, 2007).

Since the emergence of the Internet in the 90s, political parties have been adapting themselves to the new tools provided by the Web 2.0 to the rhythm of the technological innovations and the process of citizen appropriation, in such a way that each election has been accompanied by numerous technopolitical innovations: blogs, video channels on YouTube, social networks, etc. (Dader, 2009). Thus, while the Internet seemed to give parties a platform to recover the political message (Bimber and Davis, 2003), i.e., to bypass the media machinery and reach militants and voters through websites (Sey and Castells, 2006; Chadwick, 2006), the Internet has been gradually incorporated as another element of the overall campaign strategy.

Despite the technological optimism that accompanied the expansion of the Internet, several studies about the partisan use of Internet generally suggest that parties have used these tools as a forum to deploy their persuasivestrategic discourse and attract media attention, rather than to recover a di-

2 This study has been realized under the research project Communication flows in processes of political mobilization: the media, blogs and opinion leaders (MEDIAFLOWS) (2014-2016), funded by the Spanish Ministry of Economy and Competitiveness (Ref. cso2013-43960-R). Its principal researcher is Guillermo López, Professor of Journalism at the Department of Theory of Languages and Communication at the University of Valencia. 
rect link with voters (Norris, 2003), ${ }^{3}$ especially in the Spanish context (Dader, 2009; Dader et al., 2011). In this way, the accumulated experience seems to confirm the normalization hypothesis, namely, the idea that the technopolitical practices of the Internet reproduce the main features of the offline campaigns (Druckman, Kifer and Parkin, 2010; Schweitzer, 2009). In other words, political actors are using the Internet mainly in order to foster marketing purposes, not to stimulate political pedagogy or to promote debate among citizens. But the political use of the Internet is not limited to electoral processes. There is, in fact, an intense academic debate on the impact of digital communication on the form and practice of politics in Western democracies. Scholars generally agree that the Internet has notably opened bottomup communication channels in political processes (Gibson and Römmele, 2007; Castells, 2009). More specifically, ICTs have been conceived as a tool to face the growing citizen dissatisfaction towards democracy (Bentivegna, 2006), since social media allow for the direct contact between political actors and citizens and provide for new ways of political engagement. In that sense, cyber-optimist scholars claim that the Internet has positive effects on political participation (Lévy, 2004; Jenkins, 2008), especially intensifying the participation of people already interested in politics (Dader, 2001, 2003) or even reaching new groups (Rheingold, 2004). For their part, cyber-pessimists highlight the resistance to change and democratization of political elites and the lack of interest of the majority of the citizenry in politics (Davis, 2001; Anduiza et al., 2010).

\subsection{Emotions in political discourse}

Political communication scholarship has primarily showed a formalist approach when analyzing online political discussions, ${ }^{4}$ since most researchers have relied on normative notions of deliberation and operationalized its different conditions (Dahlgren, 2000; 2005; Camaj et al., 2009; Freelon, 2010; Ruiz et al., 2010; Valera, 2012; 2014a).

Over the last decades, several authors have emphasized that the study of emotions may help understand social behavior and collective action processes.

3 Among the exceptions, it is worth mentioning the innovative use of ICT in some foreign campaigns, such as those of Howard Dean (Sey et al., 2006;Jenkins, 2008; Dader, 2009), Ségolène Royal (Montero, 2009) and Barack Obama (Turiera-Puigbò, 2009).

4 To the best of our knowledge, Graham (2010) is among the few scholars who have taken a tentative to move beyond the formal notions of deliberation. His research analyzed the interaction between deliberation and humor, emotional comments and acknowledgments. 
According to Collins (1999), emotions bind society and motivate initiative in social interaction.

Different scholars point out the crucial role of emotions in constructing the identity of social movements (Melucci, 1995; Goodwin, Jasper and Polletta, 2001), since they play a key role in gathering people together, providing a sense of group identity and promoting collective action to achieve specific purposes. This crucial role of emotions does not imply that social movements' members are simply irrationally driven or have no long-term commitment to it. Even though the emotional energy is the primary attractor, there are people who internalize these emotions, and who are strongly motivated and committed to the cause in rational terms.

According to Collins (2001), the collective rituals that take place within social movements generate two different emotional transformations. At the time of the movement formation, emotions tend to be mostly negative, since their members experience certain aspect of social life as deeply unfair and therefore mobilize to design a plan for action. In fact, one of the means for social movements to defy their enemies is the recreation of this initial vigor. Then, however, the group generally transforms the negative feelings into positive emotions, which strengthen the sense of group identity and solidarity.

This study constitutes an exploratory research into the presence of emotions in electoral discourse through social media. We assume that emotions were particularly important in Podemos' discourse during the European election campaign for different reasons. First, the party emerged a few months before the elections with a strong heritage of different organizations, such as the platform РAH (Plataforma de Afectados por la Hipoteca), ${ }^{5}$ or the $15 \mathrm{M}$ Movement, etc. Second, researchers have pointed out the prevalence of persuasion and emotional appeals in the use of ICT by political parties during electoral campaigns.

The research questions that guided this study are the following:

- What kind of content prevails in Podemos' political discourse on Facebook? Does the party focus on ideological and programmatic stances or does it rather insist on campaign issues?

5 Platform of People Affected by Mortgages (Plataforma de Afectados por la Hipoteca in Spanish) was a citizens' response to the generalized housing problems that emerged after the economic crisis and the end of the construction bubble, when a lot of citizens lost their jobs and started to be unable to pay their mortgages. Banks would then retain the house property and evict them from their homes. Platform actions have been primarily directed to stopping evictions and trying to negotiate with the banks alternative solutions. 
- What kind of emotions does the party convey through its Facebook profile? Do they harp on existing negative feelings such as mistrust and cynicism towards traditional politics? Or does it run an online campaign appealing to positive emotions such as enthusiasm and hope for political change?

- What are the emotional responses of the followers to the party's discourse? Do the comments of the followers exhibit emotional involvement?

- Is there a relationship between the content of the posts and the emotions conveyed by them?

\section{METHODOLOGY}

This study analyzes the discourse of Podemos and its followers on the party's Facebook profile during the European campaign 2014 through two methodological approaches. First, content analysis is applied to all the posts published during the campaign in order to assess what types of issues were specially emphasized by Podemos. Second, the presence of emotions in both the posts and the comments is analyzed through the means of a pragmatic linguistic approach.

\subsection{Sample and time frame}

The corpus consists of all the posts published by Podemos in its Facebook profile during the official time frame of the electoral campaign in Spain $\left(9^{\text {th }}\right.$ to $23^{\text {rd }}$ May 2014). These posts with all their respective comments were retrieved and saved by means of the research software NodeXLGraph. ${ }^{6}$ In total, 163 posts and 7578 comments were collected. The analysis focuses on all the posts published by the party $(n=163)$ and a sample of the comments. In order to select the sample, five posts were randomly chosen (post number $7,56,80,93$ and 161) and all the corresponding comments $(n=215)$ were included in the analysis.

6 Available at: http://nodexl.codeplex.com/. 


\subsection{Content analysis}

The content of the posts was categorized according to the classification scheme of electoral discourse proposed by López and adapted by Valera and López (2014). It includes four possible categories:

1. Ideological and programmatic issues: principles, values, ideological positions, policy proposals;

2. Campaign issues: political polling, propaganda, election ads, campaign events, debates, campaign strategies;

3. Candidates' character traits or personal issues;

4. Government management (any information evaluating the performance of a concrete government or official).

Two raters classified the content of a sample of 50 posts (30\% of the sample). Inter-rater reliability was calculated using Cohen's Kappa (k) statistics to correct for chance agreement. The overall agreement was adequate enough $(\mathrm{k}=0.62)$. As a consequence, the content rating was continued only by one rater.

In addition to this methodological design, we also analyzed the deliberative nature of the posts published by Podemos, in order to observe if its Facebook profile was actually being used for citizen deliberation. We did so through a concept elaborated by Valera (2014b) named "political density" or "deliberability", which refers to discourse that contains any statement that can be rationally debated. Generally, any post including an ideological or programmatic statement can be rationally discussed and argued among users (see example 1), while other posts including information about electoral events cannot (see example 2).

(1) We want quality public infrastructure and not projects for speculation. The caste loves spending our money benefitting his friends [...]. It's time to chase them (published $10^{\text {th }}$ May 2014). ${ }^{7}$

(2) Tomorrow at 18:00 we are organizing a big Podemos meeting in Oviedo with Pablo Iglesias, Tania González, Estefanía Torres and more people. Are you willing to miss out on it? Share it and join it! (published $13^{\text {th }}$ May 2014). ${ }^{8}$

7 "Queremos infraestructuras públicas de calidad y no proyectos destinados a la especulación. La casta es muy aficionada a gastar lo que es de todos en concesiones a sus amigos [...].Ya es hora de echarles» (ndr: all excerpts of Facebook posts have been translated by the authors).

8 «Mañana a las 18:00 hacemos un gran acto de Podemos en Oviedo con Pablo Iglesias, Tania González, Estefanía Torres y más. ¿Te lo vas a perder? ¡Comparte y participa!». 
To assess the agreement among coders, inter-rater reliability was calculated using Kappa (k). The results showed that raters were in moderate agreement $(\mathrm{k}=0.52)$. Afterwards, the 42 posts in which raters disagreed were jointly recoded and three major criteria for the subsequent coding of "deliberability" and "non-deliberability" were established.

\subsection{Linguistic analysis}

Regarding the study of emotions in political discourse, we propose a linguistic approach. Generally, two different methods have been applied to the linguistic study of emotions: sentiment analysis and pragmatic analysis. While the first tries to extract emotions through the retrieval of affective words (e.g. happy, sad, afraid, and so on) through different means (keyword spotting, lexical affinity, statistical methods, etc.), pragmatic analysis studies emotions in the context of a specific discourse.

Indeed, pragmatic research considers that «emotional words are only one way of grammatically codifying emotions in language» (Bazzanella, 2004). As a consequence, emotional language is always analyzed in the overall context of the discourse. Caffi and Janney (1994) identified six ranges of emotional devices in language, which have been successfully applied to the study of computer-mediated discourse (Laflen and Fiorenza, 2012; Vandergriff, 2013).

We chose a pragmatic approach for this exploratory study of emotions in political discourse for multiple reasons. On the one hand, Facebook posts are usually short, so the shortness may reduce the presence of explicit emotional words. On the other hand, emotional content may be masked under the metaphors commonly used in political discourse. As a consequence, in the current study the presence of emotions in discourse is analyzed using Caffi and Janney's (1994) methodology, especially focusing on two types of emotion markers: evaluation devices and proximity devices. ${ }^{9}$

The first category is based on the central distinction between positive and negative evaluations. It includes «all types of verbal and nonverbal choices that suggest an inferable positive or negative evaluative stance on the part of the speaker with respect to a topic, part of a topic, a partner, or partners in discourse» (Caffi et al., 1994, p. 354). For example, a negative evaluation device frequently repeated by Podemos is the term casta (caste), addressed

9 Other devices mentioned by Caffi et al. (1994) are: specificity devices, evidentiality devices, volitionality devices and quantity devices. 
to the major Spanish political parties.The word casta (caste) is an emotionalladen word negatively marked.

Proximity devices are based on the central distinction between near and far and include all types of linguistic choices that create a "distance" between the speaker and the partners or topics (Caffi et al., 1994, p. 356). Among the most frequent devices in this category the use of deixis can be mentioned (personal pronouns, temporal markers, social proximity markers, etc.). Podemos made an attentive use of the first person plural pronouns (we, our). The inclusive 'we' creates proximity with the interlocutor and involve him in the political choices, a stratagem frequently used in political discourse (cfr. for example Wilson, 1990). Indeed, the name of the party itself, Podemos, ${ }^{10}$ is the first person plural of the verb poder (to can), which clearly echoes Barack Obama's 2008 presidential campaign slogan «yes, we can».

Therefore, the emotional content of the posts and the comments was analyzed paying attention to both evaluation devices (emotional-laden lexical choices) and proximity devices (use of pronouns and deixis to create proximity or distance with followers). The posts were analyzed indicating whether they conveyed emotions (yes or no). Posts containing emotions were subsequently classified according to the polarity of the emotions (positive, negative or both). To assess the agreement of the coders, inter-rater reliability was calculated using Kappa (k). The results showed that raters in this study were in substantial agreement about the presence of emotions in the posts $(\mathrm{k}=0.68)$ and in moderate agreement regarding the polarity of the posts $(\mathrm{k}=0.48)$; due to the qualitative nature of the study, these results were considered adequate and posts in which raters disagreed were jointly recoded.

\section{RESULTS}

In general quantitative terms, Podemos' Facebook use during the electoral campaign showed a continued activity on the profile. The party posted 163 posts in a period of 14 days (average 11,64 posts per day) and received 7578 comments in total (average 46,49 comments per post).

10 In the lexical analysis of our corpus,podemos was largely the more frequently mentioned word both in the party's posts and in the comments. These results are probably attributable not only to the repetition of the name of the party, but also to the frequency of the modal verb poder (to can). 


\subsection{Thematic content of the posts}

According to the proposed content classification scheme (López and Valera, 2014), the majority of the 163 posts published by Podemos in its Facebook profile during the European electoral campaign dealt mainly with issues related to the campaign itself (Figure 1).

To be precise, $64 \%$ of the posts (104 out of 163 ) focused on information related to campaign events, campaign strategies, electoral debates, polls, propaganda or results of the election. In other words, most of the party's discourse on this social network revolved around the campaign itself, while just $33 \%$ of the posts contained some ideological or programmatic statement ( 53 out of 163). These results suggest that Podemos' use of Facebook during the European Election campaign was basically strategic, inasmuch as it focused on the campaign as a horserace.

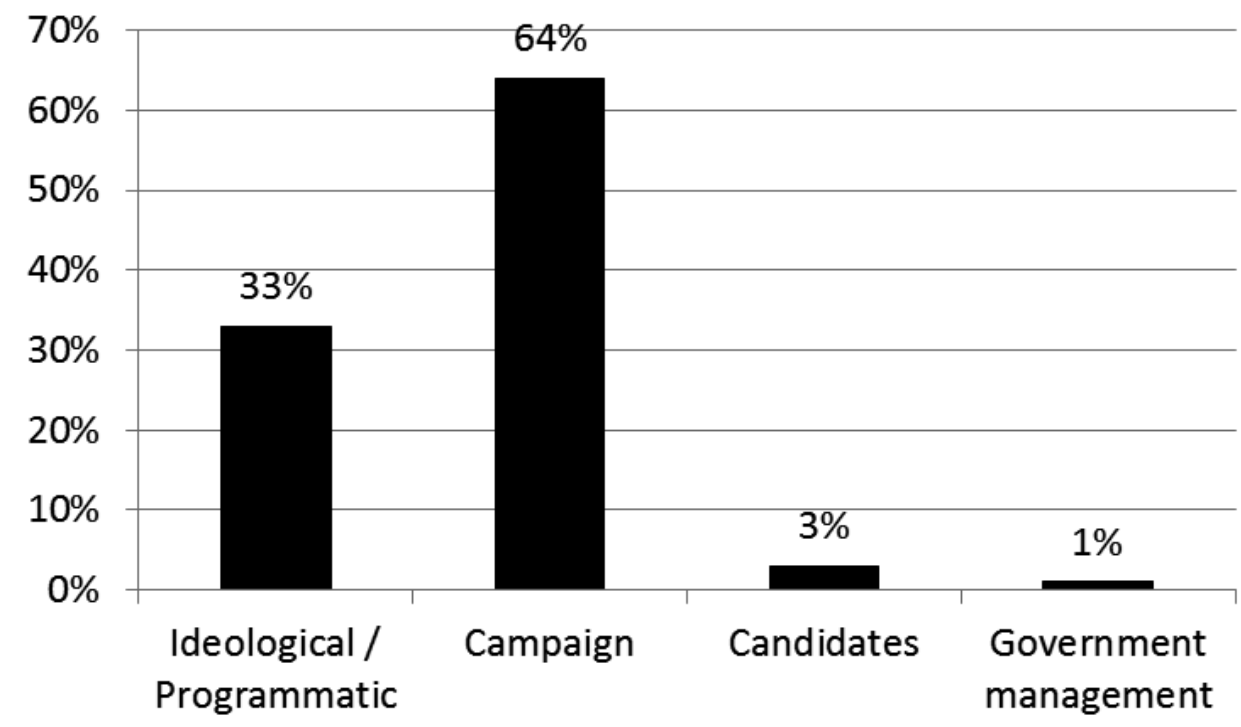

Figure 1

Type of content of Podemos' Facebook posts

For their part, only 3\% of the posts (five out of 163) contained personal information about the candidates or discussed the personality of the party's 
leaders. This shows that despite the strong leadership and great visibility of its main leader, Pablo Iglesias Turrión, Podemos avoided to run a campaign based on this leadership in social media. It rather deployed a grass roots electoral strategy trying to appeal to and mobilize the ordinary citizen.

Finally, just $1 \%$ of the posts consisted on a critique to the management of the incumbent government. This result seems particularly striking, since most of Podemos' public discourse has consisted on a fierce and well-justified critique to the traditional political parties and their management on different levels of government. However, the results suggest that this rather negative strategy was substituted by a more constructive discourse during the campaign, as the analysis of emotions will point out later on.

Moreover, the analysis of the political density shows that the posts presented slight more "non-deliberability". Table 1 reveals that, in fact, $52 \%$ of the posts (84 posts out of 163) did not contain any statement that could be rationally discussed among the followers, but were centered on specific campaign information.

Table 1

Political density of the posts

\begin{tabular}{lcc}
\hline & Absolute frequency & Relative frequency \\
\hline Deliberable posts & 79 & $48 \%$ \\
Non-deliberable posts & 84 & $52 \%$ \\
\hline
\end{tabular}

In other words, more than half of the posts published by Podemos during the campaign did not contain any statement that could translate into a substantial deliberation among the followers. Instead of promoting citizen discursive interaction, most of the content was designed to publish campaign information, such as concrete campaign events taking place all around the Spanish territory, or different ways to contribute to the party's funding. Still, $48 \%$ of the posts did imply taking stances that could be debated among citizens. 


\subsection{Emotions in Podemos' discourse}

The pragmatic analysis of evaluation and proximity devices reveals that there is a consistent presence of emotions in the analyzed corpus. According to our analysis, 101 posts out of 163 included some sort of emotional content (62\%), and 62 posts (38\%) did not present any emotional content at all (Table 2).

Table 2

Emotional content of the posts

\begin{tabular}{lcc}
\hline & Absolute frequency & Relative frequency \\
\hline Emotional posts & 101 & $62 \%$ \\
Non-emotional posts & 62 & $38 \%$ \\
Total & 163 & $100 \%$ \\
\hline
\end{tabular}

Regarding the polarity of emotions, the majority of the posts had a positive-oriented emotional content ( 67 posts out of 101). This $66 \%$ of posts containing some sort of positive emotion (such as hope, enthusiasm, etc.) is in stark contrast with the $13 \%$ of the posts that presented negative emotions (such as cynicism or mistrust).

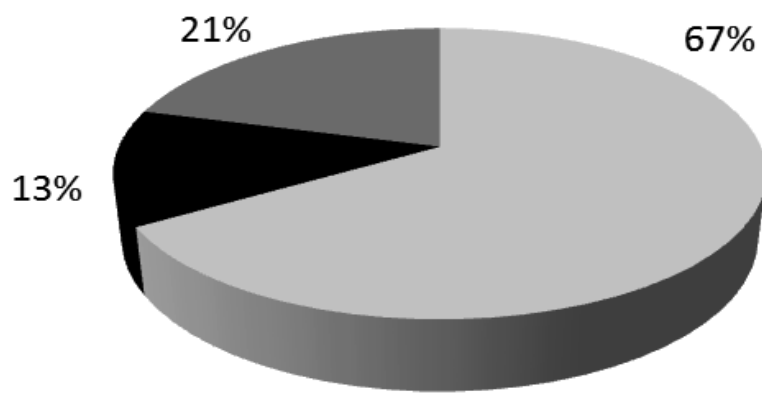

Positive $\mathbf{n}$ Negative $\square$ Both

Figure 2

Emotional polarity of Podemos' Facebook posts 
That is, the party's discourse during the campaign was characterized by a significant positive tone, as suggested previously by the content analysis. Moreover, 21\% of Podemos' publications included both positive and negative emotions (Figure 2).

\subsection{Relationship between topic and emotions}

In addition to the analysis of the presence of emotions, we asked ourselves about the possible relationship between the type of content published by the party and the presence of emotions. That is, were certain types of content more likely to contain emotions?

Table 3

Presence of emotions in different types of content (absolute values)

\begin{tabular}{llll}
\hline Type of content/ Presence of emotions & No emotions & Emotions & Total \\
\hline Ideological/ Programmatic & 9 & 44 & 53 \\
Campaign & 51 & 53 & 104 \\
Candidates & 2 & 3 & 5 \\
Government management & 0 & 1 & 1 \\
Total & 62 & 101 & 163 \\
\hline
\end{tabular}

As showed in Table 3, ideological and programmatic posts were far more likely to include emotional content in comparison to posts related to campaign issues. Indeed, ideological and programmatic posts conveyed emotions more frequently: 44 out 53 posts $(83 \%)$ included affective content. ${ }^{11}$ The association of ideological and programmatic issues with the presence of emotions constitutes an interesting result, showing that the party exposed its essential ideological stances and programmatic proposals with the help of emotional devices in order to mobilize the citizenry.

11 Due to the small sample size, no further statistical tests were calculated to analyze the association between the two variables. 
For their part, campaign-related posts showed a certain degree of balance among presence or lack of emotions: 51 posts showed no emotions and 53 included some emotional content. In the case of posts about candidates, two of them showed emotional content and the only post dealing with the government management also had some emotional orientation.

Regarding the polarity of emotions, as showed in Figure 3, half of the ideological and programmatic posts contained positive emotions (22 posts out of 44), 8 posts included negative emotions and 14 posts presented both. Within the posts related to the campaign, most of them contained positive emotions ( 43 posts out of 53), while a minority included negative feelings ( 4 posts) or both positive and negative emotions ( 6 posts, $14 \%$ ). The only post about candidates clearly had a positive emotional content, and the affective charge of the post on the current government was negative.

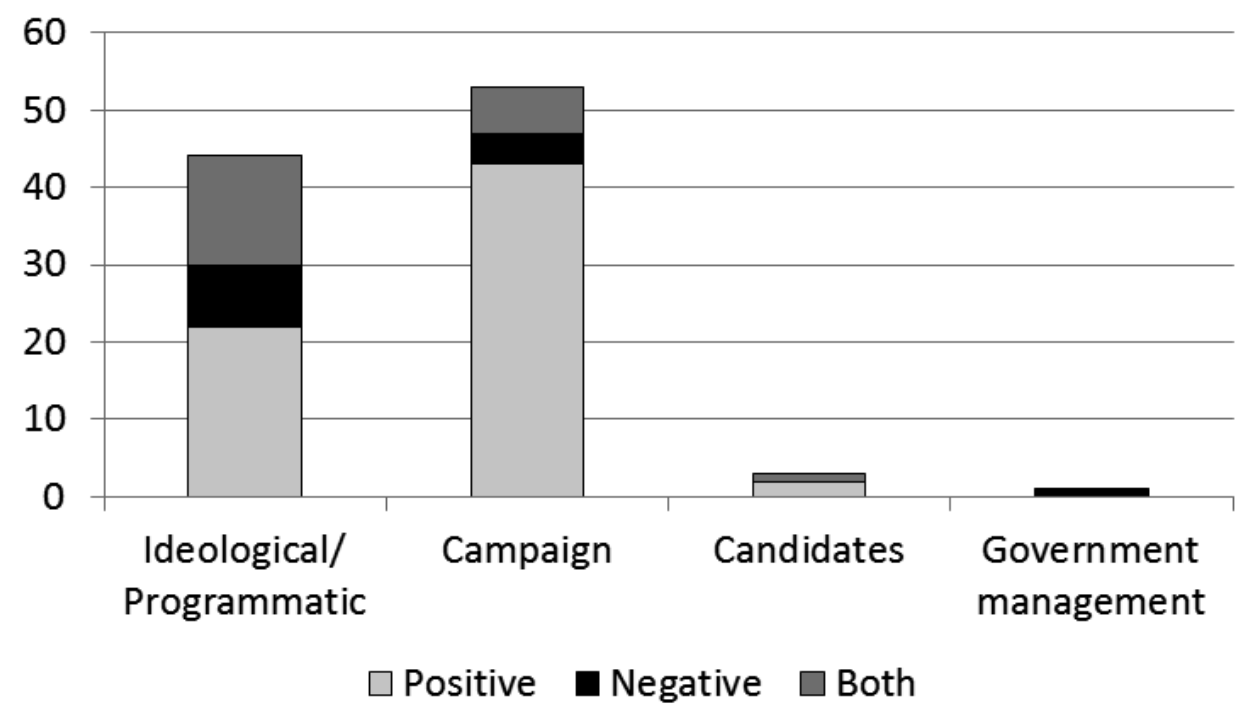

Figure 3

Polarity of emotions in different types of content 


\subsection{The presence of emotions in the comments}

Before analyzing the emotional content of the comments, it is worth considering some basic information about the posts that were randomly selected for analyzing their comments, as their content and emotional value may influence the subsequent comments (Table 4).

Table 4

Posts randomly selected for the analysis of their comments

\begin{tabular}{|c|c|c|c|c|}
\hline Post & Type of content & «Deliberability» & $\begin{array}{c}\text { Presence } \\
\text { of emotions }\end{array}$ & $\begin{array}{c}\text { Polarity } \\
\text { of emotions }\end{array}$ \\
\hline 7 & Campaign issues & No & Yes & Positive \\
\hline 56 & $\begin{array}{l}\text { Ideological and } \\
\text { programmatic } \\
\text { issues }\end{array}$ & Yes & Yes & Positive \\
\hline 80 & Campaign issues & No & Yes & Positive \\
\hline 93 & $\begin{array}{l}\text { Ideological and } \\
\text { programmatic } \\
\text { issues }\end{array}$ & Yes & Yes & Both \\
\hline 161 & Campaign issues & No & Yes & Negative \\
\hline
\end{tabular}

The results of the analysis of the 215 comments clearly show a very different pattern in comparison with the posts published by the party (Table 5 ). Most of the comments contained no emotional content at all (154 out of 215), even though programmatic issues were debated, the hope for a political change repeated in the posts related to campaign issues and posts showed different emotional polarity. Most of the users only commented once, and no real debates took place among several users, although two of the posts randomly chosen showed political density, thus theoretically opening the way to citizens' debates. Only less than one third (61 out of 215) expressed some emotion (Table 5). That is, the party deployed a much more emotional discourse in this social network than the citizens that got involved in the online political discussions. 
Table 5

Presence of emotions in the comments

\begin{tabular}{lcc} 
& Absolute frequency & Relative frequency \\
\hline No emotions & 154 & $72 \%$ \\
Emotions & 61 & $28 \%$ \\
Total & 215 & $100 \%$ \\
\hline
\end{tabular}

Regarding the polarity of emotions, the results also exhibit another interesting pattern in comparison to the party's discourse (Figure 4). Indeed, the majority of the users' comments contained expressions of negative emotions (31 out of 61), while the posts were overwhelmingly positive, as previously exposed. A third of the comments, however, expressed positive feelings (33\%), while $16 \%$ contained both positive and negative emotions.

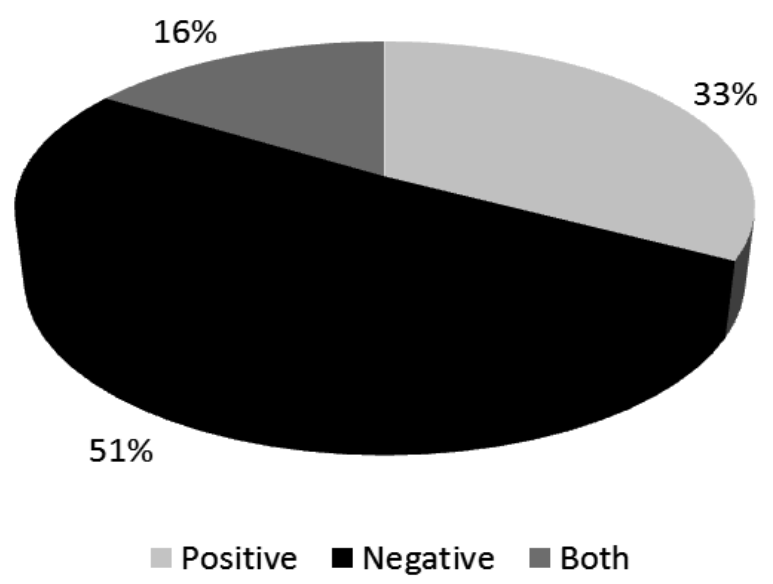

Figure 4

Emotional polarity of the comments 
In general, the expression of negative emotions in the comments by Podemos' followers refers to feelings of mistrust, cynicism and disaffection towards political elites. These negative comments, as previously exposed, are the most common, according to our results. For example, the $6^{\text {th }}$ comment of post number 7 (example 3), shows a negative orientation towards politicians:

(3) You know, what bothers me is that we are people who have very clear ideas and when they try to deceive us, they think we're stupid and we believe everything they say without consequences, that then we will not remember anything. But that is over, we are not sheep following the herd $[\ldots]^{12}$.

In contrast, positive emotional comments refer to feelings like enthusiasm and hope and they tend to be addressed to Podemos as a party and its potential to promote a political and social change in Spain. For example, the $32^{\text {nd }}$ comment of post number 80 clearly shows a positive orientation towards the party and its campaign, as shown in example 4:

(4) Today the act in Alicante was fantastic. The thrill of feeling the people get together. More than numbers, I would talk about authenticity, and in Podemos' acts you can breathe genuine enthusiasm and excitement; it's moving to see so many people together believing in the same project ${ }^{13}$.

\section{CONCLUSIONS}

The last two decades have witnessed an increasing interest of scholars in the use of the Internet in different political participation and mobilization processes. The growth and success of social networks have recently moved academic attention to these new communication platforms. In this article, we have analyzed Podemos' use of Facebook during the European election campaign, as well as the relationship between emotions and political discourse.

According to the content analysis, campaign issues clearly prevailed in the party's discourse on Facebook (such as information about multiple cam-

12 «Sabeis [sic] lo que me jode que somos gente que tenemos unas ideas muy claras y que cuando nos intentan engañar se creen que somos tontos y que nos creemos todo lo que dicen inpunemente [sic] que no vamos a recordar nada luego pero eso se acabo [sic] no somos ovejas de su rebao [sic] [...]".

13 «Tremendo hoy el acto de Alicante. La emoción de sentir que el pueblo se une. Más que de números, yo hablaría de autenticidad, y en los actos de Podemos se respira auténtica ilusión y emoción de ver a tanta gente junta creyendo en un mismo proyecto $[\ldots] »$. 
paign events, or about different ways to financially support the party), while ideological and programmatic-laden contents were less frequent. This confirms that Podemos' use of the Internet was electorally driven, since they mainly used it as a tool to deploy their persuasive-strategic discourse, instead of trying to recover a direct link with voters or promote citizen deliberation (Dader et al., 2011). In that sense, our results with regards to the topics and the limited "deliberability" (Valera, 2014b) of the posts contribute to ratify the normalization hypothesis (Schweitzer, 2009; Druckman et al., 2010).

Despite the formal bias of political communication research when dealing with online political discussions, this study presents an exploratory research of the presence of emotions on the party's discourse. Emotions are considered important in the emergence and strengthening of political and social movements (Collins, 2001), such as the 15M Movement (Belli and Díez, 2013), the Obama's campaign 2008 (Castells, 2009), or the MAS movement in Bolivia (Errejón, 2012).

Following a pragmatic linguistic approach, this research has shown a significant presence of emotions in Podemos' discourse on Facebook. These emotions were mainly positive during the campaign, since the party repeatedly appealed to feelings like enthusiasm and hope for a political change to promote mobilization. These results are in big contrast with Podemos' public discourse before the campaign, which consisted on a well-justified and systematic critique of the traditional Spanish political parties.

Moreover, our results reveal that ideological and programmatic posts were more likely to contain emotions, thus confirming the idea that emotions play an important role in processes of political and social mobilization, especially in the early stages of the building of a new political and social movement (Collins, 2001). But there were also some negative emotions found in Podemos' discourse, mainly associated to Spanish traditional political parties. That is, Podemos' discourse during the campaign 2014 was consistently presented with an emotional tone, mainly positive (hope for a change and confidence on the party) but also negative (critiques and attacks against the "caste").

According to the analysis of emotions in the development of social movements elaborated by Collins (2001), movements start from negative feelings against people, institutions or organizations that threaten their main values, and then they move to more positive feelings, such as pride or hope. The negative emotions of the $15 \mathrm{M}$ Movement were addressed to traditional political actors and institutions, which were considered corrupted, degraded and inadequate to solve social problems. In that sense, our analysis of emotions in 
both the party's discourse and the comments shows a very interesting result and a marked discrepancy.

On the one hand, the results suggest that Podemos tried to convert these first negative emotions against traditional parties into positive feelings during the campaign, placing itself in the political scenario as a source of hope and change, as argued by Collins (2001) in his conception of the two emotional stages of social movements.

On the other hand, just a minority of followers' comments had some emotional content and most of them showed a lack of political density. In their majority posts were simple repetitions of campaign slogans, or questions about practical campaign issues, and citizens rarely involved in real political debates. Moreover, emotionally laden comments mainly conveyed expressions of negative emotions, such as mistrust or cynicism, in stark contrast with the party's predominant positive emotional tone. It is therefore reasonable to assume that the party's support and its surprising electoral mobilization were achieved through the negative motivations of its followers. In other words, while the party was already trying to move to a more positive discourse that could transform the citizen disenchantment into social change, the electoral base of the party remained mainly at an earlier stage, expressing negative feelings against traditional political actors and politics in general.

In conclusion, this study constitutes a first attempt to analyze the presence of emotions in political discourse through social networks. Due to the exploratory nature of the study, several limitations should be noted. First, the qualitative nature of the method used to identify emotions hinders a generalization of the results. Even though inter-rater reliability was statistically calculated and considered adequate, a subjective bias in the analysis of the data remains. Another limitation refers to the size of the sample, especially in the case of the comments, which impose a prudent discussion of the results. Future research with bigger samples of comments will have to establish if these results are generalizable. Finally, future research will also have to study the presence of emotions in political discourse in non-electoral periods. Comparative studies could also analyze the emotional dimension of multiple parties' discourse. Moreover, the deliberative dimension of online political discussions could also be considered in more detail, through a more extensive analysis of followers' interactions and participation. 


\section{REFERENCES}

Anduiza, E., Cantijoch, M., Gallego, A. And SAlCEdo, J. (2010): Internet y participación política en España, Madrid, Centro de Investigaciones Sociológicas. [http://libreria.cis.es/static/pdf/OyA63a.pdf]

Bazzanella, C. (2004): «Emotions, Language, and Context» in Weigand, E. (ed.). (2004): Emotion in Dialogic Interaction:Advances in the Complex, John Benjamins, pp. 59-78. [doi 10.1177/0267323106066638]

BeLLI, S. and DíEz, R. (2013): «Una aproximación al papel de las emociones en la nueva ola de indignación global: la ocupación de espacios físicos y nofísicos», paper presented at the \#15Mp2p meeting, Barcelona, IN3.

Bentivegna, S. (2006): «Rethinking Politics in the World of ICT», European Journal of Communication, 21, 3, pp. 331-343.

BImber, B. and Davis, R. (2003): Campaigning Online:The Internet in U.S. Elections, New York, Oxford University Press.

CAFFI, C. and JANNEY, R.W. (1994): «Toward a pragmatic of emotive communication", Journal of Pragmatics, 22, pp. 325-373.

Camaj, L., Hong, S. C., Lanosga, G. and Luo, Y. (2009): «Political Discourse on Facebook: A New Public Sphere? ", Annual meeting of the Association for Education in Journalism and Mass Communication, Sheraton Boston, Boston, ma, Aug 05, 2009. [http://www.allacademic.com/meta/p375074_ index.html]

Castells, M. (2009): Comunicación y poder, Madrid,Alianza Editorial.

CHADwick,A. (2006): Internet Politics, States, Citizens and New Communication Technologies, New York, Oxford University Press.

Coluins, R. (2001): " Social Movements and the Focus of Emotional Attention » in Goodwin, J., Jasper, J.M. and Polletta, F. (eds.) (2001): Passionate Politics: Emotions and Social Movements, Chicago, University of Chicago Press, pp. 27-44.

DADER, J. L. (2001): «La ciberdemocracia posible: reflexión prospectiva a partir de la experiencia en España ", Cuadernos de Información y Comunicación (CIC), 6, pp. 177-220. [http://www.redalyc.org/articulo. oa?id=93500609]

- (2003): «Ciberdemocracia y comunicación política virtual: el futuro de la ciudadanía electrónica tras la era de la televisión " in Berrocal, S. (comp.). (2003): Comunicación política en televisión y nuevos medios, Barcelona,Ariel, pp. 309-342.

- (2009). Ciberpolítica en los websites de partidos políticos. La experiencia de las elecciones de 2008 en España ante las tendencias transnacionales. 
Revista de Sociología Política, 17(34), 45-62. [http://www.scielo.br/pdf/ rsocp/v17n34/a05v17n34.pdf]

Dader, J. L., Campos, E., Vizcaíno-Laorga, R., and Cheng, L. (2011): «Las web de los partidos españoles durante la campaña para las elecciones generales de 2008: pautas de cibermarketing con pocos signos de ciberdemocracia " in SAMPEDRO,V. (ed.) (2011): Cibercampaña. Cauces y diques para la participación. Las elecciones generales de 2008 y su proyección tecnopolítica, Madrid, Editorial Complutense, pp. 145-194.

DAHLGREN, P. (2000): «L'espace publique et l'Internet: Structure, espace et communication ", Réseaux, 18, 100, pp. 157-186.

- (2005): «The Internet, Public Spheres, and Political Communication: Dispersion and Deliberation ", Political Communication, 22, 2, pp. 147-162. [doi: 10.1080/10584600590933160]

DAVIs, R. (2001): «Tecnologías de la comunicación y democracia: el factor Internet ", Cuadernos de Información y Comunicación (CIC), 6, pp. 9-32. [http://www.redalyc.org/pdf/935/93500602.pdf]

Druckman, J., Kifer, M. and Parkin, M. (2010): "Timeless Strategy Meets New Medium. Going Negative on Congressional Campaign Web Sites, 2002-2006 ", Political Communication, 27, pp. 88-103. [doi: 10.1080/10584600903502607]

ERRejón, I. (2012): La lucha por la begemonía durante el primer gobierno del MAS en Bolivia (2006-2009): un análisis discursivo, unpublished doctoral dissertation, Madrid, Universidad Complutense de Madrid [http:// eprints.ucm.es/14574/1/T33089.pdf]

Freelon, D. G. (2010): «Analyzing online political discussion using three models of democratic communication ", New Media and Society, 12, 7, pp. 1172-1190. [doi: 10.1177/1461444809357927]

Gibson, R. and Römmele, A. (2007): «Political Communication » in Caramani, D. (ed.) (2007): Comparative Politics, Oxford, Oxford University Press, pp. 1-59.

Goodwin, J., JasPer, J.M. and POlletta, F. (2001): «Why Emotions Matter» in Goodwin, J., Jasper, J.M. and Polletta, F. (eds.) (2001): Passionate Politics: Emotions and Social Movements, Chicago, University of Chicago Press, pp. $1-24$.

GrAHAM,T. (2010): «The use of expressives in online political talk: Impeding or facilitating the normative goals of deliberation? " in TAMBOURIs, E, MACINTOSH, A. and Glassey, O. (eds.) (2010): Electronic Participation, Vol. 6229, Berlin, Springer, pp. 26-41. 
Howard, P. N. (2005): «Deep Democracy,Thin Citizenship:The Impact of Digital Media in Political Campaign Strategy», Annals of the American Academy of Political and Social Science, 597, 1, pp. 153-170.

Jenkins, H. (2008): Convergence Culture: La cultura de la convergencia de los medios de comunicación, Barcelona, Paidós.

LAFLEN,A. and FiorenzA, B. (2012): “'Okay, My Rant is Over':The Language of Emotion in Computer-Mediated Communication",Computers and Compositions, 29, 4, pp. 296-308. [http://dx.doi.org/10.1016/j.compcom.2012.09.005]

LÉvy, P. (2002/2004): Ciberdemocracia. Ensayo sobre Filosofía Política, Barcelona, UOC.

MAAREK, P. (2009): Marketing político y comunicación. Barcelona, Paidós Ibérica.

Melucci,A. (1995): «The Process of Collective Identity » in Johnstons, H. and

Montero, M. D. (2009): «E-mobilització i participació polítiques en les campanyes electorals de Ségolène Royal (2007) i Barack Obama (2008)», Quaderns del CAC, 33, pp. 27-34.

Klandermans, B. (eds.) (1995): Social Movements and Culture, Minneapolis, University of Minnesota Press, pp. 41-63.

Norris, P. (2003): «Preaching to the Converted?: Pluralism, Participation and Party Websites ", Party Politics, 9, 1, pp. 21-45.

RHeINGOLD, H. (2004): Multitudes inteligentes: la próxima revolución social, Barcelona, Gedisa.

Ruiz, C.P., Masip, J. L., Díaz-Noci, J. and Domingo, D. (2010): «Conversación 2.0. y democracia:Análisis de los comentarios de los lectores en la prensa digital catalana», Comunicación y Sociedad, 2, pp. 7-39.

SANJú́n, M. (2015): "Nuevas formaciones políticas crecidas en Internet y su entrada en las Elecciones Europeas 2014: el caso de Movimiento RED, Podemos, Recortes Cero y Partido X», Digitos, 1, pp. 71-89. [http://www. revistadigitos.es/pdf/Digitos-1-Sanjuan.pdf]

SEy, A. and Castells, M. (2006): «De la política en los medios a la política en Red: Internet y el proceso político » in CASTELLS, M. (ed.) (2006): La sociedad red: una visión global, Madrid,Alianza Editorial, pp. 440-463.

SCHWEITZER, E. (2009): "Innovation or Normalization in E-Campaigning? A Longitudinal Analysis of German Party Web Sites in the 2002 and 2005 National Elections ", Paper prepared for presentation at the 67th Annual Conference of the Midwest Political Science Association, April 2-5, 2009, Chicago, IL, usA.

Swanson, D. and Mancini, P. (1996): «Patterns of Modern Electoral Campaigning and Their Consequences » in Swanson, D. and Mancini, P. (eds) (1996): 
Politics, Media and Modern Democracy: An International Study of Innovations in Electoral Campaigning and Their Consequences. Westport, Praege, pp. 247-276.

Tracy, S. J. (2013): Qualitative research methods: Collecting evidence, crafting analysis, communicating impact, Hoboken, NJ, Wiley-Blackwell.

VAlerA, L. (2012): «Deliberation or Radicalized Partisan Discourse? The online political discussion on the Facebook profiles of Spanish political candidates», Textual and Visual Media, 5, pp. 311-340. [http://www.textualvisualmedia.com/images/revistas/05/articles/Deliberation.pdf]

- (2014a): «El debate público en la blogosfera política española durante la campaña electoral 2011: ¿Hacia un espacio público enriquecido o fragmentado?», Trípodos, 34, pp. 153-170. [http://www.tripodos.com/index. php/Facultat_Comunicacio_Blanquerna/article/view/170]

- (2014b): Agenda building y frame promotion en la campaña electoral de 2011: La circulación del discurso entre partidos, medios y ciudadanos, unpublished doctoral dissertation, University of Valencia.

[http://roderic.uv.es/bitstream/handle/10550/38908/Lidia\%20Valera.\%20 Tesis\%20biling\%C3\%BCe.pdf? sequence $=1$ \&isAllowed $=y$ ]

VAlera, L. and López, G. (2014): «Agenda and frames in the websites of the People's Party (PP) and the Spanish Socialist Workers' Party (PSOE) in the 2011 cyber campaign", Revista Latina de Comunicación Social, 69, pp. 41-66. [http://www.revistalatinacs.org/069/paper/1000_Valencia/03_ Valeraen.html].

VANDERGRIFF, I. (2013): «Emotive communication online: A contextual analysis of computer-mediated communication (CMC) cues", Journal of Pragmatics, 51, pp. 1-12. [http://dx.doi.org/10.1016/j.pragma.2013.02.008]

WILSON, J. (1990): Politically Speaking: the pragmatic analysis of political language, Oxford, Basil Blackwell. 